\title{
Business Model Enriched With User Experience, as a Systemic Tool in Service Design
}

\section{Jadranka Musulin}

Faculty of Organization and Informatics, University of Zagreb, Croatia and VERN University, Croatia

jadranka.musulin@vern.hr

\section{Vjeran Strahonja}

Faculty of Organization and Informatics, University of Zagreb, Croatia

vjeran.strahonja@foi.hr

\author{
CroEconsur \\ Vol. 23 \\ No. 2 \\ December 2021 \\ pp. $67-103$
}

Received: June 29, 2021

Accepted: October 4, 2021

Review Article

doi:10.15179/ces.23.2.3

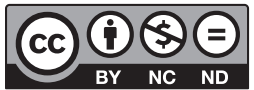

\section{Abstract}

Service design and business model design are considered in the literature as separate approaches to value creation for the customer. User experience, as a concept that represents a holistic emotional and meaningful result of the interaction with information technologies, is nowadays an important ingredient of the customer value. This paper aims to theoretically set the ground for using the business model concept as a systemic tool in service design that will support the design for user experience. Against this background, we ask: Can the business model concept successfully represent a system that is required for the value proposition-based service exchange? We investigate this question based on service-dominant logic and accompanying service science, and semantically compare elements of the service system, service ecosystem, and ten service science basic concepts. The 
analysis shows that the business model canvas, the chosen model for business model representation, satisfies the systemic perspective and can serve as a system platform for integrating with service design.

Keywords: business model, service design, user experience, service science, service-dominant logic

JEL classification: L21, L86, M15, M21

\section{Introduction}

Service design and business model design are still considered in methodological and practical terms as two separate approaches to value creation for the customer. What they have in common is that both approaches nowadays consider user experience as an important aspect of the customer value. User experience (UX), a concept that represents an overall result of the interaction between a user and an information technology (IT) artefact, has become a desirable service value ingredient in contemporary business models. Analysis of the respective literature shows that the holistic and phenomenological UX concept has not been embedded in existing service design and business model methods. The infusion of latest information technologies into products and services opens new opportunities for value creation but poses many challenges at the same time. To successfully engage the customer, enable a service, and enhance value proposition through IT, management needs a digital strategy aligned with the business model and ecosystem (Saarikko, Westergren, \& Blomquist, 2017). To achieve strategic digital alignment with the value proposition, a business model concept could be formalized and employed to act as a systemic tool when designing services focused on the value of user experience.

Attempts to match service design and business model design, as two separate approaches to value creation for the customer, are scarce in the literature. The integration of the business model into service design is in its infancy as service design usually lacks the commercialization aspect (Witell, Snyder, Gustafsson, 
Fombelle, \& Kristensson, 2016). While the integration of different perspectives in service design is a common subject of academic discussion (Patrício, Fisk, Falcão e Cunha, \& Constatine, 2011; Wetter-Edman et al., 2014; Ostrom, Parasuraman, Bowen, Patrício, \& Voss, 2015; Teixeira et al., 2017; Patrício, Gustafsson, \& Fisk, 2018), very few works elaborate business model and service design alignment (Kleinschmidt, Burkhard, Hess, Peters, \& Leimeister, 2016; Chew, 2016).

Nevertheless, the business model concept potential to act as a design tool for setting a systemic strategic ground to the service and experience design has been recognized in the literature. Kindström and Kowalkowski (2014) notice that innovations are too focused on the service newness disregarding other business model elements that can be a source of new opportunities and change. Following a design science research approach, Kleinschmidt et al. (2016) define two principles for aligning service design and business model design via the value proposition: (1) determining the customer experience outcome, and (2) determining the scale and scope of the service innovation. Also following a design science research approach, Chew (2016) attempts to include the business model into the service design methodologically by presenting the iSIM method which involves both a design and a commercialization aspect organized in seven design process elements (service strategy, customer type / value proposition, service concept, service system, customer experience, service architecture, and monetization).

Although the importance of linking and aligning business models and service design is recognized in research, there are many open questions since “... integrative change within research traditions takes time", among other things, to "... examine overlaps and complementarities that advance service design as an interdisciplinary research area" (Patrício et al., 2018, p. 6). In that vein, this paper examines the overlapping of the business model concept and the service system concept to set the ground for employing a business model concept as a systemic strategic tool in service design generally or specifically for user experience. The link to experience design can be found in open questions regarding the development of integrative new tools that should in practice enable the following: (1) application of holistic principles in service studies based on 
value co-creation (Maglio \& Spohrer, 2013); (2) clear formalization of operating constructs (Chew, 2016); and (3) design as an open inquiry as opposed to the problem-solving approach (Kimbell, 2011; Patrício et al., 2018). To this end, this paper investigates theoretical underpinnings for an explicit representation of a service system through the business model concept focusing on the experiential value proposition. The main research question guiding this review article is: Can the business model concept successfully represent a system that is required for the value proposition-based service exchange?

The paper is structured as follows. After this introductory section, the second section establishes theoretical underpinnings of the main research concepts, namely business models, service design, and related fields. The third section justifies a service-dominant logic approach and the business model positions taken. The fourth and fifth sections contain a review of service system representations and a semantic analysis of conceptual matching with the business model concept. In the final section, the findings are summarized and the intended employment of the business model concept in service design is proposed.

\section{Service Design, Business Model, New Service Development, and Service Innovation}

Service design can be defined as "applying design methods and principles to the design of services" (Holmlid \& Evenson, 2008, p. 341). Service design combines multiple areas of expertise such as service marketing, service operations, and interaction design with the aim to holistically understand customer context, envision future service solutions, and prototype them (Patrício et al., 2018). To this end, service design is based on applying specific methods that share common characteristics such as human-centeredness, co-creation, interdisciplinarity, and a holistic approach (Moritz, 2005; Kimbell, 2009; Stickdorn \& Schneider, 2011; Segelstrom, 2013; Clatworthy, 2013). 
Service design is present at multiple levels of abstraction. At the highest level of abstraction, the strategic level, the result of service design is a service concept (Goldstein, Johnston, Duffy, \& Rao, 2002), while at lower levels of abstraction, down to the operations, service design envisions a service system comprising work system elements for service delivery (Alter, 2012). This hierarchy of abstraction levels can be found in many service design conceptualizations. For example, according to Edvardsson, Gustafsson, Sandén, and Johnson (2000), service design encompasses service concept, service system, and service process. Likewise, Patrício et al. (2011) develop a service design method based on three hierarchical levels: (1) service concept (representing value proposition in user context), (2) service system (comprising system architecture), and (3) service encounter (expressing service experience). Despite these examples of congruent thinking, service design is still a poorly understood concept, and its scope is variable (Kimbell, 2011; Patrício et al., 2018), but, generally, a service system is always present in the service design (purposely or not) and emanates from the service concept itself. With or without a formalization, a service needs a service system as a set of interconnected elements that act together in service creation. Therefore, a service system is a critical concept for service concept implementation, whose conceptual characteristics are very close to a business model with regard to the formalization issue.

In service science, service systems are defined as "value-co-creation configurations of people, technology, value propositions connecting internal and external service systems, and shared information" (Maglio \& Spohrer, 2008, p. 18). In that vein, a service system represents the approach for value co-creation conceptual abstraction which should empower analysis, design, and formalization of this complex process (Maglio \& Spohrer, 2013), which is one of the goals of the business model concept as well.

The business model concept appeared in literature and practice "as a new unit of analysis" (Zott, Amit, \& Massa, 2011, p. 1019) which embraces a mechanism for value creation outside the traditional boundaries of the value chain, the firm, 
or the industry. A business model is expressed through a simplified aggregated display of key elements needed for profitable customer value creation. Elements of business models vary in different approaches, but the main common focal element is always the value proposition (Maglio \& Spohrer, 2013; Wirtz, Pistoia, Ullrich, \& Göttel, 2016) around which other elements, such as customers, partners, channels, technologies, finance, etc., should be built. Both the business model and the service design intend to tailor and describe the way to create value for a customer using key resources and processes, while in the first case the financial construction is required, and in the second it is not.

A significant overlapping of the business model, the service system, and the service design concept is already evident from these fundamental literature considerations. Considering their common purpose of value creation, it is also apparent that these concepts share a common goal and should be matched to achieve that value from different points of view. But alignment of the value proposition, and other elements, in business models and service systems is not fully realized (Chandler \& Lusch, 2015), which leads to service innovation failures (Kindström \& Kowalkowski, 2014). Service design and business model design processes are usually separated, as is the evaluation of their respective outcomes, which endangers the creation of the value promised to customers and company performance (Kleinschmidt \& Peters, 2017). The service concept, both as a new or an innovated offering, must be mirrored in other business model elements, meaning that the service design process is inseparable from the business model design or innovation.

Apart from the previously identified main overlapping concepts, namely service design, service system, and business model, there are two more concepts that are related to the issue of designing services - new service development and service innovation, which should be discussed prior to the integration of the service design and the business model. Service design was traditionally considered as one of the new service development stages, but later, its scope expanded to various phases of the new service development process, intersecting exploration, ideation, 
reflection, and implementation phases (Patrício et al., 2018). Nowadays service design can be seen as a new creative approach that reforms the process of new service development based on the notion of value co-creation (Yu \& Sangiorgi, 2018). Comparing these two approaches, new service development can be characterized as systematic and structured, whereas service design is more open, creative, and flexible in order to holistically embrace a value co-creation concept (Patrício et al., 2018).

Service innovation, compared to service design and new service development, can be characterized as an outcome, while the other two are seen as processes (Patrício et al., 2018). However, the service innovation concept is also scattered and poorly defined (Snyder, Witell, Gustafsson, Fombelle, \& Kristensson, 2016), changing over time, and spanning its meaning from improving only one activity within a firm (demarcation perspective) to disrupting new offerings on the market (assimilation perspective) (Witell et al., 2016). The shared characteristic of all different approaches to service innovation is the existence of new value creation which is the backbone of the synthesis perspective (Witell et al., 2016). Business model innovation is seen as one type of service innovation (Martin, Gustafsson, \& Choi, 2016), making the business model concept a structured ground for encompassing a service concept and a service system in the service design of new or improved services.

Figure 1 depicts the conceptual relationships of the previously discussed overlapping concepts - new service development, service design, service innovation, and business model. This visual representation is generated according to their fundamental characteristics emphasizing the following points:

- New service development is a formally structured process.

- Service design appears along the new service development process complementing it by adding specific methods and techniques, a creative and holistic approach, and iterative activities. The three flags denoting moments 
of service design symbolize multiple and multidimensional service design activities that are not firmly structured.

- Service innovation appears as the result on the right side of the figure, representing the outcome of the new service development process and/or service design activities.

- The business model concept represents a service innovation in whole or just implements it in certain elements.

Figure 1: Conceptual Relationships of New Service Development, Service Design, Service Innovation, and Business Model

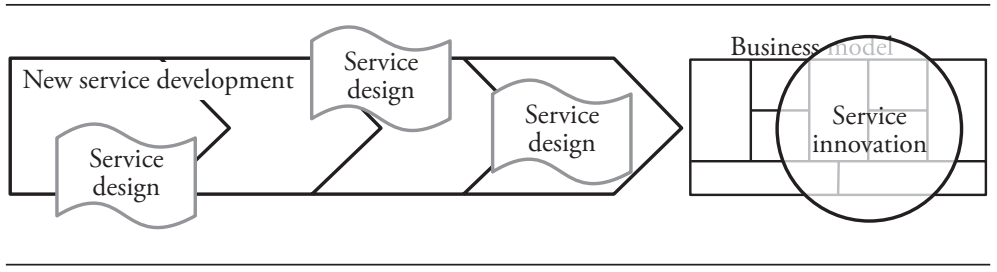

Source: Authors' own elaboration.

Relationships from the presented model in Figure 1 can partially be found in various single perspectives and individual disciplines but have nowhere been all put together. For example, in the service marketing field, the role of service design is seen as "crucial ... at various stages of the chain of events leading up to customer experienced value and organizational success" (Andreassen et al., 2016, p. 25). There is also a conceptual framework that matches the one presented in this paper, where service design is positioned as a nonlinear set of activities present in various points for organizational change and enhanced value creation. 


\section{Service-Dominant Logic for a Service View in Business Models}

Service-dominant logic (SDL) expresses a novel marketing perspective that unifies contemporary marketing ideas concerning fundamental motives for market exchange, the mode and the place of value creation, and the roles of suppliers, customers, and other resources (Vargo \& Lusch, 2004, 2006, 2008, 2016; Lusch \& Vargo, 2014). The main ideas behind SDL thinking, which made the greatest shift from traditional views, are: (1) a service is the foundation of every market exchange (even in the case when a customer buys a physical product, the product is considered a service carrier), and (2) a customer is always a co-creator of the value rendered from the service, determining that value uniquely and phenomenologically (meaning that the value for a customer cannot be determined in advance and delivered). SDL enveloped converging service centered ideas and organized them in a set of clear premises formulating a service perspective that has had a tremendous impact in the whole marketing community and wider, in the extent that no one ever managed before (Grönroos, 2011).

SDL can provide a theoretical grounding for the alignment of service design and the business model concept based on the notion that every business is a service business. SDL also provided fundamentals for the service science field whose "ultimate goal is to apply scientific understanding to advance our ability to design, improve, and scale service systems for business and societal purposes" (Maglio \& Spohrer, 2008, p. 20) by considering a service as any mutual value creation between entities, no matter of the industry sector and type of product. Service science aims to unite efforts of service studies from different disciplines such as marketing, management, engineering, design, computing, economics, and social sciences, to thoroughly understand service systems, and to obtain efficient tools for service innovations (Maglio \& Spohrer, 2013).

According to SDL, a service is the application of competencies for the benefit of another entity (Vargo \& Lusch, 2004). Within service science, Maglio and 
Spohrer (2013) reinterpret the original SDL definition by highlighting the role of co-creation and define a service as value co-creation among distinct entities. This view of a service broadens its boundaries far beyond the service sector scope. Every business can be seen as a service business because in every business at least two entities encounter with their resources and together create value in many ways. Consequently, every business is a service system, defined as an integration of resources needed for value co-creation, differing in size from an individual to the global economy. In that vein, every economy is a service economy, every business is a service business, every exchange is based on a service, and every business model is a service business model.

Based on SDL, and its accompanying service and service system conceptualizations, value co-creation represents a foundation for building a service system and a related business model. Service design is focused on designing a value proposition, the central element of a business model, followed by other dependent business model elements, that is, service system resources that need to be integrated. The differences between the business model concept and service system stem from their scope, objective, formalization, and other determining categories.

Exhaustive decomposition of these two concepts is hardly possible because of a lack of a common approach in defining the scope, functions, and elements of these concepts. Business model is a widely accepted term in practice gaining popularity ever since the internet began to significantly change traditional businesses. From that time, every new form of creating value in business is labelled as a new business model, implying various phenomena with no theoretical grounding. In academic literature, this conceptual scattering caused the emergence of different approaches to studying business models leading to isolated silos of research like e-business types, value creation or value capture by firms, and how technology innovation works (Zott et al., 2011). Although with time a convergence of approaches could be noticed (Wirtz et al., 2016; Foss \& Saebi, 2017) towards understanding the business model as a conceptual design or architecture of the mechanism for profitable customer value creation, the scientific discussion on the business model 
definition is ongoing (Baden-Fuller \& Morgan, 2010; Arend, 2013; Massa, Tucci, \& Afuah, 2017), attempting to organize different conceptual streams. Baden-Fuller and Morgan (2010, p. 167) inferred that "business models have a multivalent character as models" after identifying three possible roles: (1) they provide means to describe and classify businesses, (2) they operate as sites for scientific investigation, and (3) they act as recipes for experimentation by managers. Zott et al. (2011, pp. 1035-1036) came to a similar conclusion suggesting that "the term business model ... is not one concept; it is many concepts". They propose a two-dimensional structure of the field by setting three focuses (e-business archetypes, activity system, and cost/revenue architecture) and four themes (a new unit of analysis, system-level holistic understanding of a business, boundaryspanning activities, and emphasizing value creation) in business model studies. After fifteen years of intensive scholarly investigations on business models, Massa et al. (2017) affirm that scholars still endlessly debate on the definition of the business model, suggesting that three different interpretations of the concept are the source of confusion, namely: (1) business models as attributes of real firms, (2) business models as cognitive/linguistic schemas, and (3) business models as formal conceptual representations of how a business functions.

These three prominent attempts to structure and organize fragmented research on business models are briefly presented to depict deep issues in setting the ground for the theoretical integration of the business model and service design through the service system by identifying their overlapping. For dealing with the construct validity of the business model concept, authors (Zott et al., 2011; Massa et al., 2017) strongly advise that in every work on business models, researchers should explicitly acknowledge their stance to these possible interpretations of the term as a starting point of theory building. Answering that call, the position in this work follows.

In this paper, the theory building regarding the business model concept rests on the following assumptions: 
1) Business model represents a formal conceptual representation of how a business functions. In relation to the previously presented Massa et al. (2017) categorization of business model conceptualizations, this is the third recommended interpretation of the concept. In this sense, business models, in some formal way (graphic, mathematical, or symbolical) explicitly describe key organizational resources required for customer value creation and profit. This approach is chosen because it is most complementary to service design methods which use a lot of visualizations (Segelström, 2009). Service design methods abound with techniques of intuitive, easily understandable, visual representations of resources and activities, and are therefore compatible to integrate with this business model approach. Formal conceptual representation facilitates the articulation, transfer, combining, and shaping of knowledge and ideas for a successful service improvement or innovation.

2) Business model canvas, founded by Osterwalder (2004) and refined by Osterwalder and Pigneur (2010), is a well-suited model and tool for a formal conceptual representation of how a business functions (Massa et al., 2017) that will be used in this paper for matching with a service system for service design. Analysis of the respective literature shows that the business model canvas has proved, both in theory and practice, to be the most popular and successful business model representation (Massa et al., 2017; John, Kundisch, \& Szopinski, 2017; Ojasalo \& Ojasalo, 2015; Bonakdar, 2015). Various formal business model representations differ in the level of abstraction (Massa et al., 2017) that also affects the complexity of the model. Generally, models represent a simplification of the real phenomenon, but the ratio of complexity and reality determines the model's usefulness. The business model formal representation should not be overcomplicated because, in that case, it would be difficult to understand it and use it (D'Souza, van Beest, Huitema, Wortmann, \& Velthuijsen, 2015). A model comprising a large number of variables represents reality more completely, but it can be less useful because of its complexity. The business model canvas, compared to other formal 
representations (e.g. McCarthy, 1982; Sonnenberg, Huemer, Hofreiter, Mayrhofer, \& Braccini, 2011; Allee, 2000; Weill \& Vitale, 2001; Gordijn \& Akkermans, 2003; Pynnonen, Hallikas, \& Savolainen, 2008; Samavi, Yu, \& Topaloglou, 2009; Casadesus-Masanell \& Ricart, 2010; Gassmann, Frankenberger, \& Csik, 2014) has achieved a fascinating success (John et al., 2017) by optimizing the level of abstraction and the number of constituent elements to provide an enough robust structure, and the space for creativity and design at the same time.

3) In order to be focused on value co-creation, a business model should be viewed from the perspective of SDL and its propositions. In that sense, SDL revolutionizes the approach to value creation and the understanding of products and services in business models. According to SDL, a service is the basis of every economic exchange, no matter whether a customer buys a physical product (e.g. a mobile phone) or a standard service (e.g. a massage). In both cases, it is a service exchange, whereas in the first case, a product is the service carrier (a mobile phone is providing a communication service, an entertainment service, etc.). Therefore, when considering a business model for a particular value proposition, the overall offering is always a service based on which a value is created. This way, business models and service design are in an inevitable conjunction, universally in all industries and sectors. Besides this service view, SDL also emphasizes that the value is always phenomenologically determined by the customer, while various actors from the service ecosystem participate in the process of value creation. Following the SDL propositions, business models must provide a platform for a phenomenological approach to value (experience) creation and an aspect of a wider ecosystem that also integrates resources outside of the firm's boundaries.

The importance of SDL for a successful and viable business model has been recognized in the literature but is still under investigation from different points of view. Ojasalo and Ojasalo (2015) notice that firms do not have tools and do not know how to apply service thinking into their business, therefore they develop 
a service business model canvas based on the business model canvas and service logic principles. Clauß, Laudien, and Daxböck (2014) investigate how a service approach influences existing business models and develop propositions explaining key issues of adjustment in the areas of transaction content, transaction structure, and transaction governance. Blaschke, Haki, Riss, and Aier (2017) deal with the issue of developing new management methods based on the business model concept and the shift to SDL. They generate four principles for design guidance, namely, ecosystem-oriented management, technology-oriented management, mobilization-oriented management, and co-creation-oriented management, contributing to the application of SDL theoretical discourses in organizational practice. Pfeiffer, Krempels, and Jarke (2017) build a service-oriented business model framework to address the specific needs of modeling value co-creation in digitally transforming ecosystems. Wieland, Hartmann, and Vargo (2017) elaborate on the business model concept from the marketing literature view and a systemic holistic approach of SDL, setting the ground for understanding a business model's need to envelop dynamic relationships within service ecosystems.

The examples from the literature show that researchers strive to find ways to shift business logic to service focus by applying SDL principles to business models, but the results are still mostly obtained on the conceptual level. It is evident that there is a need to widen the business model perspective from the traditional, firm- or close network-bounded view to a holistic systemic approach where value creation is seen in a wider, service process-based ecosystem. It can even be presumed that the business model concept should evolve into a service ecosystem concept. It can also be said that the perspective should evolve from firm-centric to servicecentric, and from single-sided (a firm) to multiple-sided (actors). In that sense, the business model canvas has been criticized for promoting "... the use of building blocks that are arranged in a manner that clearly highlights a unidirectional value flow from firm to customers and narrowly assigns development activities to focal firms and their partners" (Wieland et al., 2017, p. 937). Attempts to improve the business model canvas have emerged (e.g. Zolnowski, 2015; Ojasalo \& Ojasalo, 
2015; Pfeiffer et al., 2017), but none of them have made enough impact to replace the original model. This paper also deals with the improvements needed by the service logic shift, but the standpoint of this research is that the business model canvas does not need radical changes to implement SDL. It should be enough to add certain aspects of the service approach that can be obtained with a few clear messages inside the semantics of business model elements and by adding complementary tools to include the service design perspective.

From the previously presented aspects of SDL and their influence on business models, it is apparent that the inseparability of the business model concept and the service ecosystem concept is present, but unclear. Since the literature lacks adequate representation of the service ecosystem concept, the matching of the two concepts is hindered, and it has not been explicitly presented in the literature. Therefore, to theoretically set the ground for the business model concept as the systemic view in service design, the business model concept and the service (eco)system concept will be structurally analyzed next.

\section{Service (Eco)System Concept Representation}

Maglio and Spohrer (2008) established service science, a new transdisciplinary field for service research, based on the SDL paradigm and service systems as the fundamental units of analysis. Maglio, Vargo, Caswell, and Spohrer (2009) propose that the service system is the basic abstraction in the new worldview which broadens the perspective from products and production to services and value co-creation. The founders and protagonists of the two most comprehensive revolutionary integral perspectives based on the central role of the service in organizations, markets, society, and the world, Maglio et al. (2009) and Vargo and Lusch (2016), highlight the importance of a systemic approach and define the service (eco)system congruently (Table 1). However, neither of them established a model of the service (eco)system as a formal representation of its elements and structure. The lack of such a model impedes efforts of service design to improve 
service systems, and the establishment of a business model as a basis for financial viability. These two fundamental definitions of the basic concept will be further semantically analyzed in this chapter.

Table 1: Definitions of Service System and Service Ecosystem

\begin{tabular}{|c|c|c|}
\hline Source/reference & Concept & Definition \\
\hline $\begin{array}{l}\text { Service science: } \\
\text { Maglio et al. } \\
(2009, \text { p. } 399)\end{array}$ & $\begin{array}{l}\text { Service } \\
\text { system }\end{array}$ & $\begin{array}{l}\text { Dynamic value co-creation configuration of resources, } \\
\text { including people, organizations, shared information (language, } \\
\text { laws, measures, methods), and technology, all connected } \\
\text { internally and externally to other service systems by value } \\
\text { propositions. }\end{array}$ \\
\hline $\begin{array}{l}\text { SDL: } \\
\text { Vargo and Lusch } \\
(2016, \text { pp. 10-11) }\end{array}$ & $\begin{array}{l}\text { Service } \\
\text { ecosystem }\end{array}$ & $\begin{array}{l}\text { "Relatively self-contained, self-adjusting system of resource- } \\
\text { integrating actors connected by shared institutional } \\
\text { arrangements and mutual value creation through service } \\
\text { exchange." }\end{array}$ \\
\hline
\end{tabular}

Sources: Maglio et al. (2009) and Vargo and Lusch (2016).

Maglio and Spohrer (2008) explain that many disciplines (e.g. economics, law, organizational theory, industrial engineering, computer science, cognitive science, anthropology) have collected the knowledge for understanding service systems by focusing on different aspects, but the abstraction of the holistic service system concept is yet to be developed (Maglio et al., 2009). However, ten years after the inception of this development by service science, the issue of the service system's formal representation has not had an effective solution. Barile, Lusch, Reynoso, Saviano, and Spohrer (2016) state that the service system research has difficulties in crossing the firm boundaries and dyadic interactions with customers to address complex dynamic business configurations. To solve this problem, they call for lifting the level of analysis through three aspects: systems, networks, and ecosystems, admitting that much work is still needed in that sense.

A look at the selected work on service system ontologies shows a struggle with basic concepts taken from service science narratives. Katzan (2009) presents one of the early attempts to systemize the concepts in service science ontologically by formulating concepts, relations, and vocabulary, which was not particularly noticed in the research community. Mora, Raisinghani, Gelman, and Sicilia 
(2011) propose a service system ontology, called onto-ServSys, through an initial model of integrated conceptualizations and interrelationships in the domain of service systems with the aim to reduce and manage the cognitive complexity of multiple concepts gathered from various fields and fragmented literature. This initial model is a wide collection of concepts, respectable for its completeness, but difficult to operate with. The collected concepts are mapped against ten basic concepts of service science, defined by Spohrer and Kwan (2009), as proof of alignment with the fundamentals of service science. Lyons and Tracy (2013) also use ten basic service science concepts as a basis for modelling a service system. They develop a framework as a taxonomy that can be used to characterize an organization as a service system which seems very helpful in raising consciousness about service capabilities.

Apart from the conceptualizations based on service science foundations, in various literature (e.g. design, business management and strategy, operations research, industrial engineering, information systems) there are many normative frameworks for describing a service system. Analysis of the literature shows five types of respective frameworks, namely physical/topological, experiential, functional/process, value chain, and data-driven/simulation frameworks (Glushko, 2013). Table 2 presents a summary of these five types of service system frameworks and their characteristics. Among these, business models appear as a functional or process type of service system framework. 
Table 2: Types of Service System Frameworks

\begin{tabular}{|c|c|c|}
\hline Type of framework & Characteristics & Example or reference \\
\hline Physical/topological & $\begin{array}{l}\text { Describes physical context in which } \\
\text { customers move during service } \\
\text { encounters }\end{array}$ & Servicescape (Bitner, 1992) \\
\hline Experiential & $\begin{array}{l}\text { Describes whole environment } \\
\text { in interaction touchpoint from } \\
\text { customer perspective }\end{array}$ & $\begin{array}{l}\text { Service journey (Zomerdijk \& Voss, } \\
\text { 2010) } \\
\text { Customer journey } \\
\text { Service blueprint (Bitner, Ostrom, \& } \\
\text { Morgan, 2008) }\end{array}$ \\
\hline Functional/process & $\begin{array}{l}\text { Describes goals and components of } \\
\text { service system }\end{array}$ & $\begin{array}{l}\text { Enterprise architecture, process } \\
\text { model, activity diagrams (UML, } \\
\text { BPMN), business models, SOA, } \\
\text { XML specifications }\end{array}$ \\
\hline Value chain & $\begin{array}{l}\text { Describes incremental value adding } \\
\text { sequential activities }\end{array}$ & Production systems \\
\hline Data-driven/simulation & $\begin{array}{l}\text { Describes arrangement and } \\
\text { movement of resources in service } \\
\text { system with precise quantitative data } \\
\text { and computational models }\end{array}$ & $\begin{array}{l}\text { Simulation models (queuing, } \\
\text { scheduling, multiobjective } \\
\text { optimization) }\end{array}$ \\
\hline
\end{tabular}

Source: Authors' summary based on Glushko (2013).

In this short review of service system representations from a service science perspective, typical attempts of formalization development are presented. Based on this review, it can be concluded that service system representation still lacks a common framework that will unite different perspectives. Recent sources continue to report on this open question, calling for more ontological work on system components (Frost \& Lyons, 2017), but, again, work is streaming in partial perspectives. For example, Blaschke, Haki, Aier, and Winter (2018) develop a value co-creation ontology that reflects SDL in information systems analysis and design. Altogether, in most works that seek to develop a formalization of a service system within service science principles (e.g. Mora et al., 2011; Lemey \& Poels, 2011; Lyons \& Tracy, 2013), the conceptualization starts from ten basic service science concepts. Since none of the proposed representations has been widely accepted, the ten basic service science concepts presented in Table 3 will also be used in this paper to delineate a service system and compare it to the business model concept. In addition, the respective definitions of a service system and a service ecosystem will be decomposed and visualized. 
Table 3: Basic Service Science Concepts

\begin{tabular}{|c|c|}
\hline Concept & Description \\
\hline Resources & $\begin{array}{l}\text { Potentially useful things. Resources can be physical/nonphysical, with rights/ } \\
\text { without rights. Basic resources are people, organization, information, and } \\
\text { technology. }\end{array}$ \\
\hline Entities & $\begin{array}{l}\text { Configurations of resources that co-create value. Most common types are people } \\
\text { and organizations. An entity is also a kind of a service system. }\end{array}$ \\
\hline Access rights & $\begin{array}{l}\text { Social norms and legal regulations that impact resource access and usage. Typical } \\
\text { access rights are owned, leased, shared, and privileged. }\end{array}$ \\
\hline $\begin{array}{l}\text { Value co-creation } \\
\text { interactions }\end{array}$ & $\begin{array}{l}\text { Entities' activities performed in a service exchange for the value proposition co- } \\
\text { creation. In a narrow sense, this is the mechanism that is called a business model. }\end{array}$ \\
\hline $\begin{array}{l}\text { Governance } \\
\text { mechanisms }\end{array}$ & Activities that are performed by authority entity to ensure a conflict resolution. \\
\hline Outcomes & Results of a service exchange. Ideally, they represent a created value. \\
\hline Stakeholders & $\begin{array}{l}\text { Perspectives to value. Main types are customer, provider, authority, and } \\
\text { competitor. }\end{array}$ \\
\hline Measures & $\begin{array}{l}\text { Indicators that correspond to stakeholders' perspectives: quality, productivity, } \\
\text { compliance, and sustainable innovation. }\end{array}$ \\
\hline Networks & Entities linked by relationship patterns of interactions. \\
\hline Ecology & The universe of all service system entities. \\
\hline
\end{tabular}

Source: Authors' summary based on Spohrer and Kwan (2009).

Ten basic service science concepts have been introduced by Spohrer and Kwan (2009) as a start to understanding the value co-creation mechanisms. Table 3 summarizes the original elaboration in the form of short explicit statements for every concept. These concepts are presented to contribute to a more integrated view of a service system in the following analysis.

Next, definitions of a service system and a service ecosystem (Table 1) will be conceptually analyzed and depicted (Figure 2 and Figure 3 ) in order to extract and clarify the main concepts for the succeeding comparison. These figures visualize the concepts and their relations based on the related definitions. 
Figure 2: Service System Definition Conceptual Framework

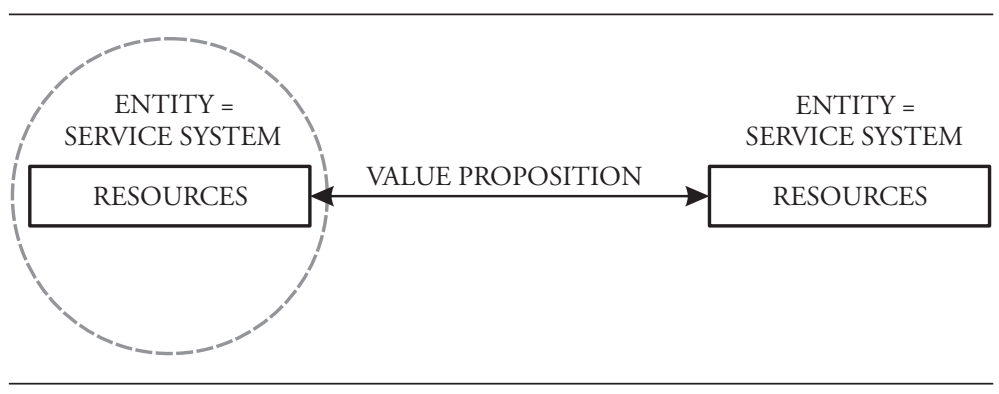

Source: Authors' visualization based on Maglio et al. (2009).

Figure 2 depicts a service system conceptual framework according to the definition by Maglio et al. (2009). This conceptualization emphasizes the entity perspective in the value exchange by equating the elementary service system with an entity. Two or more service system entities are linked through interaction based on the value proposition, creating service system networks. The scope of such a service system concept is determined only by its constituent resources, which makes a too narrow view regarding the totality of service design elements. Therefore, the sufficiency of this concept as a unit of analysis in service design is questionable. A wider perspective of an ecosystem is also present in ten basic service science concepts but is somewhat marginalized, which authors have finally realized and have called for broadening perspectives and lifting the level of analysis (Barile et al., 2016).

Figure 3: Service Ecosystem Definition Conceptual Framework

\begin{tabular}{|c|c|c|}
\hline \multicolumn{3}{|c|}{ SERVICE ECOSYSTEM } \\
\hline ACTORS & $\begin{array}{l}\text { INSTITUTIONAL } \\
\text { ARRANGEMENTS }\end{array}$ & RESOURCES \\
\hline \multicolumn{3}{|c|}{ SERVICE EXCHANGE / INTERACTION } \\
\hline \multicolumn{3}{|c|}{ VALUE CREATION } \\
\hline
\end{tabular}

Source: Authors' visualization based on Vargo and Lusch (2016). 
Figure 3 represents a service system conceptual framework based on Vargo and Lusch's (2016) definition. In contrast to Maglio et al. (2009), Vargo and Lusch (2016) focus on the service ecosystem perspective, a wider view on the service system unit of analysis that involves all actors and resources that participate in service exchange and value co-creation. Comparing the two conceptualizations, it should be noted that they were provided in different times, which influenced the wideness of their views. Both service science and SDL had narrower views at the time of the first definition (2009), and both had broadened their views at the time of the second one (2016), which can be seen from their overall work, but they provided only the previously presented definitions at those points in time. Vargo and Lusch (2016) confirm that the service system concept from service science (Maglio et al., 2009) and their service ecosystem concept are similar, whereas the main difference is in the role of institutions. This convergence of views testifies to a general evolution of the service system concept.

In this section, the service system concept definition and representation issues have been explicated to set the ground for the following alignment of the business model concept and service system concept. As a result of the literature analysis, the basic conceptualizations taken for the subsequent alignment are: ten original service science basic concepts (Spohrer \& Kwan, 2009), concepts extracted from the service system definition (Maglio et al., 2009), and concepts extracted from the service ecosystem definition (Vargo \& Lusch, 2016).

\section{Aligning Business Model and Service System}

A corresponding widening of perspective is present in business models as is in the service system conceptualization which was previously demonstrated. Polemics on the question whether the field of business models is a new field at all or is just an expansion of theoretical perspectives within the field of strategic management still go on (Massa et al., 2017). New field or not, in business models, the traditional focus on value creation at the supply side is broadening towards 
the demand side, and further to the whole network of actors that participate in value co-creation, trying to employ various sources of competitive advantages. Thus, in the literature on business models, questions such as "How much more does a firm's ecosystem matter in explaining why some firms perform better than others?" (Massa et al., 2017, p. 95) arise. The flow from strategy, across business models, and towards a service ecosystem can be seen as widening the perspective of articulating, designing, and innovating business ideas (Figure 4).

Figure 4: Widening Perspective Towards Ecosystem

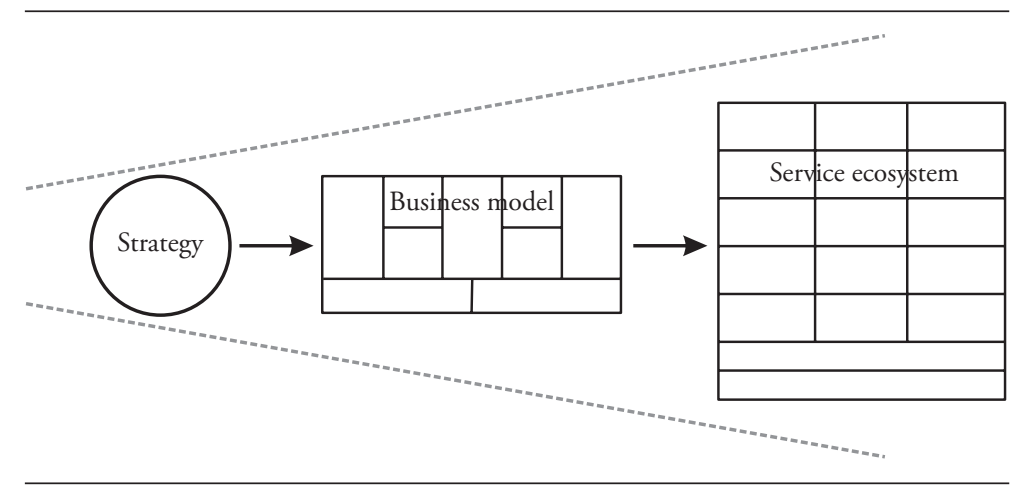

Source: Authors' own elaboration.

A strategy is focused mainly on a firm's resources for providing an offering. A business model blueprints both sides, a customer and a firm with its network, in value co-creation, but with the focus on the firm's profit. A service ecosystem includes the entire constellation of all participating actors, resources, and institutional arrangements that impact value co-creation in a service exchange. As these concepts have soft boundaries, and as they develop and evolve, this is just one of the possible interpretations which depend on the approach, level of abstraction, purpose, etc.

In order to integrate the business model concept with service design, the following question is addressed: Can the business model concept successfully represent a system 
that is required for the value proposition-based service exchange? To answer this question, a semantic analysis and matching of the business model concept with the service system, service ecosystem, and service science basic concepts follows in pairs:

- matching elements of the business model concept and service system (Table 4),

- matching elements of the business model concept and service ecosystem (Table 5),

- matching elements of the business model concept and service science basic concepts (Table 6).

Table 4: Business Model and Service System Elements

\begin{tabular}{|c|c|c|c|}
\hline Business model & 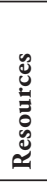 & : & 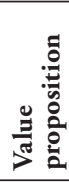 \\
\hline Value propositions & & & $\bullet$ \\
\hline Key partners & & $\bullet$ & \\
\hline Key activities & $\bullet$ & & \\
\hline Key resources & $\bullet$ & & \\
\hline Customer relationships & & & * \\
\hline Customer segments & & $\bullet$ & \\
\hline Channels & & & $*$ \\
\hline Cost structure & * & & \\
\hline Revenue streams & & & $*$ \\
\hline
\end{tabular}

Source: Authors' own elaboration based on Osterwalder and Pigneur (2010) and Maglio et al. (2009).

Table 4 shows conceptual elements matching of a business model and a service system. Black circles $(\bullet)$ indicate full semantical overlapping of the elements, and asterisks $\left(^{*}\right)$ indicate partial or indirect overlapping. For example, a key partner in a business model is an entity in a service system that is connected with other entities in realization of a value proposition. Therefore, the matching of these two 
elements is complete. But the element customer relationships is partially matched with the element value proposition because it affects the other and may be a part of it if a customer relationship represents a specific benefit that is offered to the customer. This is especially highlighted in e-services where self-service is both a type of customer relationship and a value proposition (e.g. Airbnb). In whole, the business model concept covers all elements of the service system defined by service science.

Table 5: Business Model and Service Ecosystem Elements

\begin{tabular}{l|l|l|l|l|l|}
\hline Service ecosystem & & & & \\
\hline
\end{tabular}

Source: Authors' own elaboration based on Osterwalder and Pigneur (2010) and Vargo and Lusch (2016).

Table 5 shows that business model elements cover most of the service ecosystem elements. Apart from the majority of explicit matchings, the element value propositions is matched to elements service exchange and value co-creation because it is the core of these two processes. The only uncovered service ecosystem element is institutions, which is the latest added concept in SDL, specific for the wider ecosystem view. Institutions are "rules, norms, meanings, symbols, practices, and similar aides to collaboration" (Vargo \& Lusch, 2016, p. 6) that are required to perceive a societal context which impacts the value creation. This element is lacking in the business model concept and is an emerging issue to be explored 
to make an adequate extension to the original structure of the business model representation in order to broaden its view to resource integration processes of all actors involved (Wieland et al., 2017). Although some aspects of institutions can be found in the existing business model elements which exist as consequences of institutional arrangements (e.g. resources, partners, value propositions, customer segments, etc.), the power of institutions per se for value creation mechanisms is so determining that it deserves a separate consideration to better understand the dynamics of the market. Institutions are very abstract, higher order concepts that have been investigated as key concepts for understanding human social behavior in several fields, such as sociology, organizational science, political science, and economics. They are defined differently but all definitions always stress the idea of explaining the intangible constraints determining human behavior. For example, in organizational science, Thornton, Ocasio, and Lounsbury (2012, p. 2) define institutional orders as "the socially constructed, historical patterns of cultural symbols and material practices ... by which individuals and organizations provide meaning ... and reproduce their lives and experiences". Following the institutional view, Wieland et al. (2017) define business models as "dynamic assemblages of institutions ...". Therefore, the idea of extending the business model concept with institutions is worth considering but needs much more elaboration which is out of the scope of this paper.

Table 6 shows similar matching of business model elements and service science basic concepts as in the previous comparison. Business model elements cover almost all service science basic concepts, except ecology, which is very close to the concept of institutions, because it represents a universe of entities bound with institutional mechanisms. 
Table 6: Business Model and Service Science Basic Concepts

\begin{tabular}{|c|c|c|c|c|c|c|c|c|c|c|}
\hline $\begin{array}{r}\text { Service science } \\
\text { basic concepts }\end{array}$ & 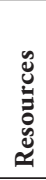 & : & 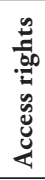 & 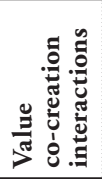 & 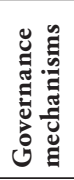 & $\stackrel{\mathscr{Z}}{\Xi}$ & $\frac{0}{\frac{0}{0}}$ & 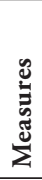 & 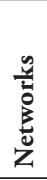 & 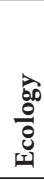 \\
\hline Value propositions & & & $\bullet$ & - & & - & & & & \\
\hline Key partners & & $\bullet$ & & & & & $\bullet$ & & $\bullet$ & \\
\hline Key activities & - & & & $\bullet$ & $\bullet$ & & & & & \\
\hline Key resources & $\bullet$ & & & & & & & & & \\
\hline Customer relationships & & & $\bullet$ & $\bullet$ & & & & & & \\
\hline Customer segments & & $\bullet$ & & & & & $\bullet$ & & & \\
\hline Channels & & & & $\bullet$ & & & & & 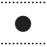 & \\
\hline Cost structure & & & & & $\bullet$ & & & $\bullet$ & & \\
\hline Revenue streams & & & & & & $\bullet$ & & $\bullet$ & & \\
\hline
\end{tabular}

Source: Authors' own elaboration based on Osterwalder and Pigneur (2010) and Spohrer and Kwan (2009).

A summary of the three presented comparisons that were designed to examine the power of the business model concept to represent a service system has two main points:

1) The business model concept in all three cases has a satisfying coverage of service system elements.

2) The business model concept is lacking an element that would embody institutional aspects that determine value creation societal context and provide a wider view beyond dyadic and even network configurations.

\section{Discussion and Conclusions}

In this paper, we address the issue of an adequate service system representation in service design for user experience that would support the ideas of service value co-creation. Since the service system concept in service science and SDL literature lacks a widely accepted formal model, we investigated the potential to use the 
business model canvas (Osterwalder \& Pigneur, 2010) as a formal representation of the service system in service design. For that purpose, the business model concept has been studied from different points of view. First, it was positioned among the vague and overlapping fields of service design, new service development, and service innovation, to clarify the close relationship between service design (process) and business models (object) in the context of developing services. Then, SDL was presented as a theoretical foundation for the alignment of service design and the business model concept based on the notion that every business model is a service business model built on the processes of value co-creation. To reduce conceptual ambiguities, persistent in the business model field, a stance towards business model conceptualization has been explicitly acknowledged in three points: (1) business model concept as a formal representation of how a business functions, (2) business model canvas as an optimal model to be used for a formal representation, (3) SDL approach in business model design to ensure phenomenological value (experience) creation. Finally, building on theoretical foundations drawn from SDL and service science, the business model concept has been matched with conceptual frameworks of service system, service ecosystem, and service science basic concepts. The alignment of conceptual elements shows that the business model concept sufficiently covers service system elements, lacking only institutional mechanisms. This identified gap is an emerging issue that should be addressed in future research to find a way to extend the business model concept in that direction. For the moment, this can be compensated with awareness of that perspective in other elements (e.g. partners, resources) and design processes (service design methods for capturing environmental context).

The purpose of this research was to theoretically ground the use of the business model concept as a tool for preserving a systemic view in service design for user experience as part of the value proposition for the customer. In this context, user experience is seen holistically and phenomenologically, as an experiential value in the form of emotions and meaning, beyond the pragmatic qualities that IT products are focused on. Such UX is nowadays present in all products and services 
since all businesses include some IT content, from just e-communication channels to various technological features in their offerings. Therefore, UX as a value needs to be infused into the business model value proposition adequately in the form of a business goal linking and aligning service design and business model (Figure 5).

Figure 5: Integration of Business Model and Service Design Through User Experience Goals

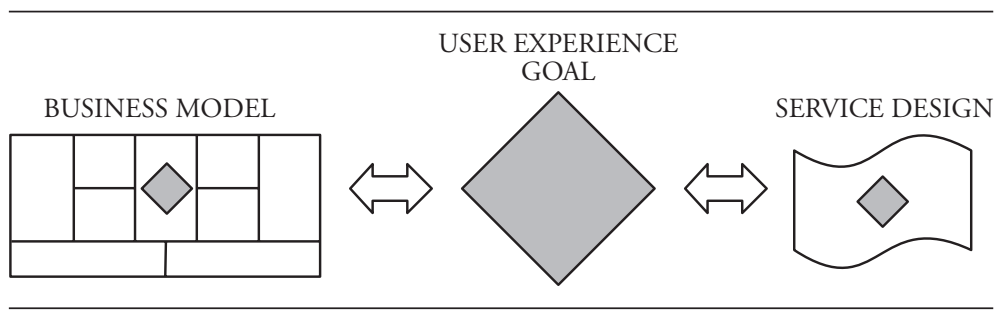

Source: Authors' own elaboration.

User experience goal can be defined as an intended feeling or meaning that the user experiences through an IT service or an IT artefact (adapted based on Lu \& Roto, 2014). After the business model concept has been determined as a convenient conceptualization of the service system in service design, its employment is further promoted by focusing on the UX goal as the key piece in the puzzle of integrating a business model and service design. The UX goal should be set in the value proposition element of the business model and continuously cared for in the application of service design methods. This research has clarified and grounded the role of the business model concept in service design for user experience, and probably for any other valuable experience in the same vein. This is a solid starting point for future empirical research that can contribute to the development of new design tools and methods in service design, UX design, and business model design. 


\section{Literature}

Allee, V. (2000). Reconfiguring the value network. Journal of Business Strategy, 21(4), 36-39. doi: https://doi.org/10.1108/eb040103

Alter, S. (2012). Metamodel for service analysis and design based on an operational view of service and service systems. Service Science, 4(3), 218-235. doi: https://doi.org/10.1287/serv.1120.0020

Andreassen, T. W., Kristensson, P., Lervik-Olsen, L., Parasuraman, A., McCollKennedy, J. R., Edvardsson, B., \& Colurcio, M. (2016). Linking service design to value creation and service research. Journal of Service Management, 27(1), 21-29. doi: https://doi.org/10.1108/JOSM-04-2015-0123

Arend, R. (2013). The business model: Present and future-Beyond a skeumorph. Strategic Organization, 11(4), 390-402.

doi: https://doi.org/10.1177/1476127013499636

Baden-Fuller, C., \& Morgan, M. S. (2010). Business models as models. Long Range Planning, 43(2), 156-171. doi: https://doi.org/10.1016/j.lrp.2010.02.005

Barile, S., Lusch, R., Reynoso, J., Saviano, M., \& Spohrer, J. (2016). Systems, networks, and ecosystems in service research. Journal of Service Management, 27(4), 652-674. doi: https://doi.org/10.1108/JOSM-09-2015-0268

Bitner, M. (1992). Servicescapes: The impact of physical surroundings on customers and employees. Journal of Marketing, 56(2), 57-71. doi: https://doi.org/10.1177/002224299205600205

Bitner, M., Ostrom, A., \& Morgan, F. (2008). Service blueprinting: A practical technique for service innovation. California Management Review, 50(3), 66-94. doi: https://doi.org/10.2307/41166446

Blaschke, M., Haki, K., Aier, S., \& Winter, R. (2018). Value co-creation ontology-A service-dominant logic perspective. In P. Drews, F. Burkhardt, P. Niemeyer, \& L. Xie (Eds.), Proceedings of Multikonferenz Wirtschaftsinformatik 2018: Data-Driven X - Turning Data Into Value (pp. 398-409). 
Blaschke, M., Haki, M., Riss, U., \& Aier, S. (2017). Design principles for businessmodel-based management methods-A service-dominant logic perspective. In A. Maedche, J. vom Brocke, \& A. Hevner (Eds.), Lecture Notes in Computer Science: Vol. 10243. DESRIST 2017: Designing the Digital Transformation (pp. 179-198). doi: https://doi.org/10.1007/978-3-319-59144-5_11

Bonakdar, A. (2015). Business model innovation (Doctoral dissertation). University of St. Gallen.

Casadesus-Masanell, R., \& Ricart, J. E. (2010). From strategy to business models and onto tactics. Long Range Planning, 43(2-3), 195-215. doi: https://doi.org/10.1016/j.lrp.2010.01.004

Chandler, J. D., \& Lusch, R. F. (2015). Service systems: A broadened framework and research agenda on value propositions, engagement, and service experience. Journal of Service Research, 18(1), 6-22. doi: https://doi.org/10.1177/1094670514537709

Chew, E. K. (2016). iSIM: An integrated design method for commercializing service innovation. Information Systems Frontiers, 18(3), 457-478. doi: https://doi.org/10.1007/s10796-015-9605-y

Clatworthy, S. (2013). Design support at the front end of the new service development (NSD) process: The role of touch-points and service personality in supporting team work and innovation processes (Doctoral dissertation). The Oslo School of Architecture and Design.

Clauß, T., Laudien, S. M., \& Daxböck, B. (2014). Service-dominant logic and the business model concept: Toward a conceptual integration. International Journal of Entrepreneurship and Innovation Management, 18(4), 266-288. doi: https://doi.org/10.1504/IJEIM.2014.064209

D’Souza, A., van Beest, N. R. T. P., Huitema, G. B., Wortmann, J. C., \& Velthuijsen, H. (2015). A review and evaluation of business model ontologies: A viability perspective. In J. Cordeiro, S. Hammoudi, L. Maciaszek, O. Camp, \& J. Filipe (Eds.), Lecture Notes in Business Information Processing: Vol. 227. ICEIS 2014: Enterprise Information Systems (pp. 453-471). doi: https://doi.org/10.1007/978-3-319-22348-3_25 
Edvardsson, B., Gustafsson, A., Sandén, B., \& Johnson, M. D. (2000). New service development and innovation in the new economy. Lightning Source Incorporated.

Foss, N. J., \& Saebi, T. (2017). Fifteen years of research on business model innovation: How far have we come, and where should we go? Journal of Management, 43(1), 200-227. doi: https://doi.org/10.1177/0149206316675927

Frost, R., \& Lyons, K. (2017). Service systems analysis methods and components: A systematic literature review. Service Science, 9(3), 219-234. doi: https://doi.org/10.1287/serv.2017.0180

Gassmann, O., Frankenberger, K., \& Csik, M. (2014). The business model navigator: 55 models that will revolutionise your business. Harlow: Pearson Education Limited.

Glushko, R. J. (2013). Describing service systems. Human Factors and Ergonomics in Manufacturing \& Service Industries, 23(1), 11-18.

doi: https://doi.org/10.1002/hfm.20514

Goldstein, S. M., Johnston, R., Duffy, J., \& Rao, J. (2002). The service concept: The missing link in service design research? Journal of Operations Management, 20(2), 121-134. doi: https://doi.org/10.1016/S0272-6963(01)00090-0

Gordijn, J., \& Akkermans, H. M. (2003). Value-based requirements engineering: Exploring innovative e-commerce ideas. Requirements Engineering, 8(2), 114 134. doi: https://doi.org/10.1007/s00766-003-0169-x

Grönroos, C. (2011). Value co-creation in servicelogic: A critical analysis. Marketing Theory, 11(3), 279-301. doi: https://doi.org/10.1177/1470593111408177

Holmlid, S., \& Evenson, S. (2008). Bringing service design to service sciences, management and engineering. In B. Hefley \& W. Murphy (Eds.), Service Science: Research and Innovations in the Service Economy. Service science, management and engineering: Education for the 21st century (pp. 341-345). Boston, MA: Springer. doi: https://doi.org/10.1007/978-0-387-76578-5_50 
John, T., Kundisch, D., \& Szopinski, D. (2017). Visual languages for modeling business models: A critical review and future research directions. Proceedings of the 38th International Conference on Information Systems (ICIS): Transforming Society With Digital Innovation, Seoul, South Korea.

Katzan, H. (2009). Principles of service systems: An ontological approach. Journal of Service Science, 2(2), 35-52. doi: https://doi.org/10.19030/jss.v2i2.4285

Kimbell, L. (2009). Insights from service design practice. Proceedings of the 8th European Academy of Design Conference, 249-253.

Kimbell, L. (2011). Designing for service as one way of designing services. International Journal of Design, 5(2), 41-52. Retrieved from: http://ijdesign.org/index.php/IJDesign/article/view/938

Kindström, D., \& Kowalkowski, C. (2014). Service innovation in productcentric firms: A multidimensional business model perspective. Journal of Business \& Industrial Marketing, 29(2), 96-111.

doi: https://doi.org/10.1108/JBIM-08-2013-0165

Kleinschmidt, S., Burkhard, B., Hess, M., Peters, C., \& Leimeister, J. M. (2016). Towards design principles for aligning human-centered service systems and corresponding business models. Proceedings of the 37th International Conference on Information Systems (ICIS): Digital Innovation at the Crossroads, Dublin, Ireland. doi: https://doi.org/10.2139/ssrn.3159144

Kleinschmidt, S., \& Peters, C. (2017). Towards an integrated evaluation of human-centered service systems and corresponding business models: A systems theory perspective. Proceedings of the 25th European Conference on Information Systems (ECIS), Guimarães, Portugal, 3060-3070. Retrieved from: https://www.alexandria.unisg.ch/publications/250828

Lemey, E., \& Poels, G. (2011). Towards a service system ontology for service science. In G. Kappel, Z. Maamar, \& H. R. Motahari-Nezhad (Eds.), Lecture Notes in Computer Science: Vol. 7084. ICSOC 2011: Service-Oriented Computing (pp. 250-264). doi: https://doi.org/10.1007/978-3-642-25535-9_17 
Lu, Y., \& Roto, V. (2014). Towards meaning change: Experience goals driving design space expansion. Proceedings of the 8th Nordic Conference on Human-Computer Interaction: Fun, Fast, Foundational, 717-726. doi: https://doi.org/10.1145/2639189.2639241

Lusch, R. F., \& Vargo, S. L. (2014). Service-dominant logic: Premises, perspectives, possibilities. Cambridge: Cambridge University Press.

Lyons, K., \& Tracy, S. (2013). Characterizing organizations as service systems. Human Factors and Ergonomics in Manufacturing \& Service Industries, 23(1), 1927. doi: https://doi.org/10.1002/hfm.20517

Maglio, P. P., \& Spohrer, J. (2008). Fundamentals of service science. Journal of the Academy of Marketing Science, 36(1), 18-20.

doi: https://doi.org/10.1007/s11747-007-0058-9

Maglio, P. P., \& Spohrer, J. (2013). A service science perspective on business model innovation. Industrial Marketing Management, 42(5), 665-670. doi: https://doi.org/10.1016/j.indmarman.2013.05.007

Maglio, P. P., Vargo, S. L., Caswell, N., \& Spohrer, J. (2009). The service system is the basic abstraction of service science. Information Systems and e-business Management, 7(4), 395-406. doi: https://doi.org/10.1007/s10257-008-0105-1

Martin, D., Gustafsson, A., \& Choi, S. (2016). Service innovation, renewal, and adoption/rejection in dynamic global contexts. Journal of Business Research, 69(7), 2397-2400. doi: https://doi.org/10.1016/j.jbusres.2016.01.008

Massa, L., Tucci, C. L., \& Afuah, A. (2017). A critical assessment of business model research. Academy of Management Annals, 11(1), 73-104. doi: https://doi.org/10.5465/annals.2014.0072

McCarthy, W. E. (1982). The REA accounting model: A generalized framework for accounting systems in a shared data environment. Accounting Review, 57(3), $554-578$. 
Mora, M., Raisinghani, M., Gelman, O., \& Sicilia, M. A. (2011). Onto-servsys: A service system ontology. In H. Demirkan, J. Spohrer, \& V. Krishna (Eds.), Service Science: Research and Innovations in the Service Economy. The science of service systems (pp. 151-173). Boston, MA: Springer.

doi: https://doi.org/10.1007/978-1-4419-8270-4_9

Moritz, S. (2005). Service design: Practical access to an evolving field. Cologne: Köln International School of Design.

Ojasalo, K., \& Ojasalo, J. (2015). Adapting business model thinking to service logic: An empirical study on developing a service design tool. In J. Gummerus \& C. von Koskull (Eds.), The Nordic school: Service marketing and management for the future (pp. 309-333). Helsinki: CERS and Hanken School of Economics.

Osterwalder, A. (2004). The business model ontology: A proposition in a design science approach (Doctoral dissertation). University of Lausanne.

Osterwalder, A., \& Pigneur, Y. (2010). Business model generation: A handbook for visionaries, game changers, and challengers. Hoboken, NJ: John Wiley \& Sons.

Ostrom, A. L., Parasuraman, A., Bowen, D. E., Patrício, L., \& Voss, C. A. (2015). Service research priorities in a rapidly changing context. Journal of Service Research, 18(2), 127-159. doi: https://doi.org/10.1177/1094670515576315

Patrício, L., Fisk, R. P., Falcão e Cunha, J., \& Constantine, L. (2011). Multilevel service design: From customer value constellation to service experience blueprinting. Journal of Service Research, 14(2), 180-200. doi: https://doi.org/10.1177/1094670511401901

Patrício, L., Gustafsson, A., \& Fisk, R. (2018). Upframing service design and innovation for research impact. Journal of Service Research, 21(1), 3-16. doi: https://doi.org/10.1177/1094670517746780

Pfeiffer, A., Krempels, K., \& Jarke, M. (2017). Service-oriented business model framework: A service-dominant logic based approach for business modeling in the digital era. Proceedings of the 19th International Conference on Enterprise Information Systems (Vol. 1), 361-372. doi: https://doi.org/10.5220/0006255103610372 
Pynnonen, M., Hallikas, J., \& Savolainen, P. (2008). Mapping business: Value stream-based analysis of business models and resources in information and communications technology service business. International Journal of Business and Systems Research, 2(3), 305-323.

doi: https://doi.org/10.1504/IJBSR.2008.020581

Saarikko, T., Westergren, U. H., \& Blomquist, T. (2017). The internet of things: Are you ready for what's coming? Business Horizons, 60(5), 667-676. doi: https://doi.org/10.1016/j.bushor.2017.05.010

Samavi, R., Yu, E., \& Topaloglou, T. (2009). Strategic reasoning about business models: A conceptual modeling approach. Information Systems and e-Business Management, 7(2), 171-198. doi: https://doi.org/10.1007/s10257-008-0079-z

Segelström, F. (2009). Communicating through visualizations: Service designers on visualizing user research. In S. Clatworthy, J.-V. Nisula, \& S. Holmlid (Eds.), Proceedings of the 1st Service Design and Service Innovation Conference, ServDes.2009 (pp. 175-185).

Segelstrom, F. (2013). Stakeholder engagement for service design: How service designers identify and communicate insights (Doctoral dissertation). Linköping University.

Snyder, H., Witell, L., Gustafsson, A., Fombelle, P., \& Kristensson, P. (2016). Identifying categories of service innovation: A review and synthesis of the literature. Journal of Business Research, 69(7), 2401-2408. doi: https://doi.org/10.1016/j.jbusres.2016.01.009

Sonnenberg, C., Huemer, C., Hofreiter, B., Mayrhofer, D., \& Braccini, A. (2011). The REA-DSL: A domain specific modeling language for business models. In H. Mouratidis \& C. Rolland (Eds.), Lecture Notes in Computer Science: Vol. 6741. CAiSE 2011: Advanced Information Systems Engineering (pp. 252-266). doi: https://doi.org/10.1007/978-3-642-21640-4_20 
Spohrer, J., \& Kwan, S. K. (2009). Service science, management, engineering, and design (SSMED): An emerging discipline - outline and references. International Journal of Information Systems in the Service Sector, 1(3), 1-31. doi: https://doi.org/10.4018/jisss.2009070101

Stickdorn, M., \& Schneider, J. (2011). This is service design thinking. Amsterdam: BIS Publishers.

Teixeira, J. G., Patrício, L., Huang, K. H., Fisk, R. P., Nóbrega, L., \& Constantine, L. (2017). The MINDS method: Integrating management and interaction design perspectives for service design. Journal of Service Research, 20(3), 240-258. doi: https://doi.org/10.1177/1094670516680033

Thornton, P. H., Ocasio, W., \& Lounsbury, M. (2012). The institutional logics perspective: Anewapproach toculture, structure, andprocess. Oxford:OxfordUniversity Press. doi: https://doi.org/10.1093/acprof:oso/9780199601936.001.0001

Vargo, S. L., \& Lusch, R. F. (2004). Evolving to a new dominant logic for marketing. Journal of Marketing, 68(1), 1-17.

doi: https://doi.org/10.1509/jmkg.68.1.1.24036

Vargo, S. L., \& Lusch, R. F. (2006). Service-dominant logic: What it is, what it is not, what it might be. In R. F. Lusch \& S. L. Vargo (Eds.), The service-dominant logic of marketing: Dialog, debate, and directions (pp. 43-56). Armonk, NY: ME Sharpe.

Vargo, S. L., \& Lusch, R. F. (2008). Service-dominant logic: Continuing the evolution. Journal of the Academy of Marketing Science, 36(1), 1-10. doi: https://doi.org/10.1007/s11747-007-0069-6

Vargo, S. L., \& Lusch, R. F. (2016). Institutions and axioms: An extension and update of service-dominant logic. Journal of the Academy of Marketing Science, 44(1), 5-23. doi: https://doi.org/10.1007/s11747-015-0456-3

Weill, P., \& Vitale, M. R. (2001). Place to space: Migrating to ebusiness models. Boston, MA: Harvard Business School Press. 
Wetter-Edman, K., Sangiorgi, D., Edvardsson, B., Holmlid, S., Grönroos, C., \& Mattelmäki, T. (2014). Design for value co-creation: Exploring synergies between design for service and service logic. Service Science, 6(2), 106-121. doi: https://doi.org/10.1287/serv.2014.0068

Wieland, H., Hartmann, N. N., \& Vargo, S. L. (2017). Business models as service strategy. Journal of the Academy of Marketing Science, 45(6), 925-943. doi: https://doi.org/10.1007/s11747-017-0531-z

Wirtz, B. W., Pistoia, A., Ullrich, S., \& Göttel, V. (2016). Business models: Origin, development and future research perspectives. Long Range Planning, 49(1), 36-54. doi: https://doi.org/10.1016/j.lrp.2015.04.001

Witell, L., Snyder, H., Gustafsson, A., Fombelle, P., \& Kristensson, P. (2016). Defining service innovation: A review and synthesis. Journal of Business Research, 69(8), 2863-2872. doi: https://doi.org/10.1016/j.jbusres.2015.12.055

Yu, E., \& Sangiorgi, D. (2018). Service design as an approach to implement the value cocreation perspective in new service development. Journal of Service Research, 21(1), 40-58. doi: https://doi.org/10.1177/1094670517709356

Zolnowski, A. (2015). Analysis and design of service business models (Doctoral dissertation). Fakultät für Mathematik, Informatik und Naturwissenschaften Fachbereich Informatik der Universität Hamburg.

Zomerdijk, L., \& Voss, C. (2010). Service design for experience-centric services. Journal of Service Research, 13(1), 67-82.

doi: https://doi.org/10.1177/1094670509351960

Zott, C., Amit, R., \& Massa, L. (2011). The business model: Recent developments and future research. Journal of Management, 37(4), 1019-1042. doi: https://doi.org/10.1177/0149206311406265 